\title{
INTAKE, DIGESTIBILITY, MILK YIELD AND COMPOSITION OF LACTATING BUFFALOES FED RATIONS SUPPLEMENTED WITH CORN GLUTEN MEAL AS NATURAL PROTECTED PROTEIN SOURCE
}

\author{
S.T.M. Fahmy, A.K.I. Abd-Elmoty, E.B. Soliman, S.M.S. Mustafa and E.M. Ibrahim \\ Animal Production Department, Faculty of Agriculture, Minia University, Egypt. \\ Corresponding E-mail: Dr_samir_fahmy@yahoo.comm
}

Received: 4/9/2019 Accepted: 17/10/2019

SUMMARY

Six lactating multiparous Buffaloes of $480 \pm 27(\mathrm{~kg})$ body weight after their peak of lactation were served in this study. Three rations nominated as T1, T2 andT3 were formulated to meet 100, 110and $115 \%$ of the buffalo's metabolisable protein (MP) requirements according to AFRC,1993 recommendations. Corn gluten meal (CGM) as a natural rumen protected protein source was added to the concentrate mixture (CM) to meet this increment in dietary MP. The control concentrate mixture (CM,T1) contained $30.80 \%$ wheat bran, $23.32 \%$ yellow corn, $17.60 \%$ soybean meal, 11\% sorghum straw, $8.89 \%$ undecorticated cotton seed meal, $5.19 \%$ Ca- salt of palm fatty acids (as ruminal protected fat),2.2\%calcium carbonate and 1\% sodium chloride. Rice straw as dry roughage and barseem (Trifolium alexandrinum) as green forage were offered as roughage source.

Corn gluten meal supplementation significantly $(P<0.05)$ increased total dry matter intake $(T D M I)$,dry matter, organic matter and crude protein digestibility's (DMD, OMD and CPD). The total digestible nutrients values (TDN) of the three tested rations were not significantly differed. The figures were 730.8, 738.2 and 743.1 $\mathrm{g} / \mathrm{kg}$ for T1,T2 and T3 respectively. Actual milk yield and 7\%fat corrected milk yield (7\%FCM) were significantly $(P<0.05)$ increased when T2 andT3 were fed in comparison with feeding T1 (the control ration). The values were 11.01,12.25 and $12.09 \mathrm{~kg} 7 \%$ FCM/day. Supplementation of CGM significantly $(P<0.05)$ increased milk protein concentrations and yield. The Concentrations were 41.5, 44.0 and $44.7 \mathrm{~g}$ protein/ $\mathrm{kg}$ milk while, the yields were $0.41,0.50$ and $0.52 \mathrm{~kg} /$ day for T1, T2 and T3 respectively. Yield of milk fat and lactose were also significantly $(P<0.05)$ increased.

It could be included that Supplementation of CGM in amount that represent 10\% above the AFRC,1993 recommendations for MP of dairy cattle positively improved intake, digestibility and milk production.

Keywords: Buffalo, digestibility, milk yield and composition and protein supplementation

\section{INTRODUCTION}

Buffaloes are one the main dairy farm animals in Egypt. Buffalo's milk represents $73 \%$ of the total available milk for human consumption in Egypt (Abu Hussein et al., 2003). The productivity of lactating buffaloes in Egypt is poor $(6-7 \mathrm{~kg} / \mathrm{head} / \mathrm{day})$. Productivity is a reflex of many factors; one of these is what they eat and how much they consumed. The major nutrients that should be available are metabolisable energy (ME) and metabolisable protein (MP).Boerman et al. (2015) stated that the high energy density of rumen-inert fat supplements increases $\mathrm{ME}$ consumption and may improve energetic efficiency through the direct transfer of fatty acids into milk. Calcium salts of palm fatty acids are advisable source of supplementary metabolisable energy that is not affected by microbial activity occurs in the reticulo- rumen and is mainly absorbed and utilized by the animal tissues (Fahmyet al., 2019).

Tripathi (2014) found that feeding dairy cows $2.7 \%$ calcium soap of fatty acids increased their milk fat yield by $8.9 \%$. On the mean time providing lactating animals with a source of ruminal undegradable protein may help post ruminal digestion and utilization(Abd-El Hakeem et al.,2017). Nichols et al. (2018) reported that, milk fat and protein corrected milk and lactose increased in response to protein and fat supplementation. Corn gluten meal (CGM) is a rich source of crude protein (more than $60 \%$ ) that is naturally of low ruminal degradability (Imran et al., 2018). In this study $115 \%$ of the metabolisable energy (ME) requirements (AFRC, 1993) for dairy cattle was applied as the ME requirements for lactating buffaloes is not available. This level of dietary ME was found to be the most convenient for lactating buffaloes (Ibrahim, 2007).

Feeding high crude protein diets, balancing rations to supply sufficient levels of amino acids in support of milk protein synthesis has been shown to improve post absorptive state $\mathrm{N}$ efficiency and increase milk protein yield (Arriola Apelo et al., 2014). Thus, great focus has been placed on maximizing dietary protein utilization by increasing post ruminal supply of amino acids and energy precursors through rumen-protected products.

In this work Corn gluten meal (CGM) was supplemented to the ration in amounts that represent 0,10 and $15 \%$ of the AFRC (1993) MP requirements of dairy cattle to enrich the dietary crude protein content. 
The objective of this work is to study the effect of protein supplementation as CGM on intake, digestibility and milk yield and milk constituents of lactating buffaloes.

\section{MATERIALS AND METHODS}

Six lactating multiparous buffaloes average body weight of $480 \pm 27(\mathrm{~kg})$ were applied in this study. Buffaloes after three months of calving were used in a complete balanced two period's changeover design experiment for several treatments (Gill and Magee, 1976).

Three rations were formulated to meet 100,110 and $115 \%$ of the metabolisable protein (MP) requirements according to AFRC (1993) recommendations. Corn gluten meal as a naturally protected protein was added to the control concentrate mixture $(\mathrm{CM})$ in amounts that represent 0,10 and $15 \%$ of the AFRC MP standards, in three rations nominated as $\mathrm{T} 1, \mathrm{~T} 2$ and $\mathrm{T} 3$ respectively. The control CM (T1) was formulated to meet the more convenient level of ME (115\% of AFRC, 1993 energy requirements) for lactating buffaloes. Calcium salts of palm fatty acids was used as a source of protected fat to rise up the ME concentration of the CM. This CM (T1) supply $111.37 \mathrm{~g}$ MP and $12.91 \mathrm{MJ}$ $\mathrm{ME} / \mathrm{kg} \mathrm{DM}$.

The second treatment (T2) composed from $\mathrm{T} 1$ plus CGM in amount $(3.46 \%)$ that rise the dietary MP content up to $122.51 \mathrm{~g} \mathrm{MP} / \mathrm{kg} \mathrm{DM}(110 \%$ of the MP content in T1). The third treatment (T3) is composed from T1 plus CGM in amount $(4.94 \%)$ that rise the dietary MP content up to $128.08 \mathrm{~g} \mathrm{MP}$ $/ \mathrm{kg}$ DM (115\% of the MP content in T1). Rice straw (RS) and Barseem (B) were offered ad libitum as roughage source. The amount consumed of both RS and $\mathrm{B}$ was considered in calculation of dry matter intake (DMI). Commercial mineral mixture (Movemineral mix) was added to the $\mathrm{CM}$ as one $\mathrm{kg} / \mathrm{ton}$ beside mineral salts licking blocks that were available in front of each animal. Vitamins $\mathrm{A}, \mathrm{D}_{3}$ and $\mathrm{E}$ (Adivit C) were injected every two weeks according to NRC, (2001) requirements.

\section{Feeding and management:}

Animals were housed inside window stable for individual feeding. Fresh water was available along the experiment. Buffaloes were milked twice daily at 7 am and $5 \mathrm{pm}$, while they were individually fed at 8 am and $6 \mathrm{pm}$. Animals were weighed at the beginning and at the end of each period before morning feeding. Buffaloes were subjected to the routinely veterinary vaccination.

\section{Sampling and laboratory analysis:}

Dietary samples were collected daily in the last week of each period and a composite sample was performed. A portion of the composite sample was dried at $105^{\circ} \mathrm{C}$ in a forced air oven till constant weight for DM determination; the rest was dried at $70^{\circ} \mathrm{C}$ for constant weight, grind and kept in closely tied jars for laboratory analysis. Diets were analyzed for DM, CP, CF, EE and ash according to AOAC (2006). Non fibrous carbohydrate (NFC) was calculated as NRC (2001). Neutral detergent fiber (NDF) and acid detergent fiber (ADF) were determined according to Van Soest et al. (1991). Hemicellulose was calculated by difference (NDFADF). Grasp fecal samples were collected before feeding at $7 \mathrm{am}$ and $2 \mathrm{pm}$ for each animal on days 24 and 27 of each period, mixed, dried on $70^{\circ} \mathrm{C}$ till constant weight, grind and analyzed for DM, CP,CF, EE, NDF, ADF and ash. Digestibility's of feed nutrients were determined using acid in soluble ash as an internal marker according to Van Keulen and Young (1977). Milk yield was recoded daily and milk samples from morning and afternoon milking were collected on days 24 and 27 of each period and analyzed individually for total solids, total nitrogen and ash according to AOAC (2006). Milk fat was measured by Gerber unites (British standards institution, 1962).

\section{Statistical analysis:}

Duncan's multiple range tests were used to determine the significance among treatment means using GIM procedure of SAS (1990) for a complete balanced two period's changeover design (Gill and Magee, 1976) according to the linear model

$\mathrm{Y}_{\mathrm{ijk}}=\mu+\mathrm{A}_{\mathrm{i}}+\mathrm{P}_{\mathrm{j}}+\mathrm{T}_{\mathrm{k}}+\mathrm{E}_{\mathrm{ijk}}$

Where $\mu$ is the overall mean, $\mathrm{A}$ is the random effect of animals $(\mathrm{i}=1, \ldots \ldots .6), \mathrm{P}$ is the fixed effect of experimental period $(j=1,2), T$ is the fixed effect of dietary treatments $(\mathrm{k}=1, \ldots 3)$ and $\mathrm{E}$ is the experimental error $(0, \delta 2)$

\section{RESULTS}

Nutritional analysis data (Table 1) showed that addition of CGM as $10 \%$ or $15 \%$ of the MP requirements of the lactating buffaloes increased the CP content of the CM from 185.1 to 201.4 and $208.0 \mathrm{~g} / \mathrm{kg}$ DM . These increases were calculated to be 8.81 and $12.37 \%$ for $\mathrm{T} 2$ and $\mathrm{T} 3$ respectively above $\mathrm{T} 1$ (the control $\mathrm{CM}$ ). The concentrations of other nutrients (DM, OM, CF, NDF, ADF, NFC and NFE) were almost the same despite of the slight decrease in EE and ash in T2 and T3 in comparison with T1. Corn gluten meal (CGM) was characterized by its high content of CP $(669.5 \mathrm{~g} / \mathrm{kg} \mathrm{DM})$ and low content of $\mathrm{EE}(30.7 \mathrm{~g} / \mathrm{kg} \quad \mathrm{DM}), \mathrm{CF}(16.3 \mathrm{~g} / \mathrm{kg} \quad \mathrm{DM})$ ,NDF(120.7g/kg DM), ADF(67.0g/kg DM) and ash $(35.2 \mathrm{~g} / \mathrm{kg} \mathrm{DM})$. Rice straw as dried roughage was of low content of $\mathrm{CP}, \mathrm{EE}$ and calculated NFC. The values were $37.4,12.4$ and $46.9 \mathrm{~g} / \mathrm{kg} \quad \mathrm{DM}$ respectively. While, the values were high for $\mathrm{CF}$, NDF, ADF and ash (368.8, 764.0 623.0 and 157.3 $\mathrm{g} / \mathrm{kg}$ DM respectively, Table 1). Barseem as a green forage had $144.0 \mathrm{~g} \mathrm{CP}, 14.5 \mathrm{~g} \mathrm{EE} / \mathrm{kg} \mathrm{DM}$, while it's content of CF, NDF and ADF were 293.1, 540.0 and 420.0/kg DM.

The nutrients contents of the whole ration consumed are presented in Table 3. Addition of CGM by $3.43 \%$ (T2) or $4.94 \%$ (T3) of the control 
$\mathrm{CM}$ raised the $\mathrm{CP}$ content of the whole ration by 11.14 and $15.02 \%$ respectively. Concentrations of other nutrients were almost the same despite the slight decrease in EE concentration as the values were $51.53,49.40$ and $48.36 \mathrm{~g} / \mathrm{kg}$ successively.

Dry matter intake (DMI) data are presented in Table 2. Intake of CM plus CGM as DM was significantly $(\mathrm{P}<0.05)$ increased by 6.27 and $9.97 \%$ as T2 and T3 were compared with $\mathrm{T} 1$ respectively. On the mean time addition of CGM to the lactating buffaloes ration increased the intake of RS. It was 1.25 (T2) and 1.43 (T3) times the RS intake of T1.

Table 1. Nutritional analysis of concentrate mixture, corn gluten meal, ricestraw and berseem offered to the lactating buffaloes (g/kg DM)

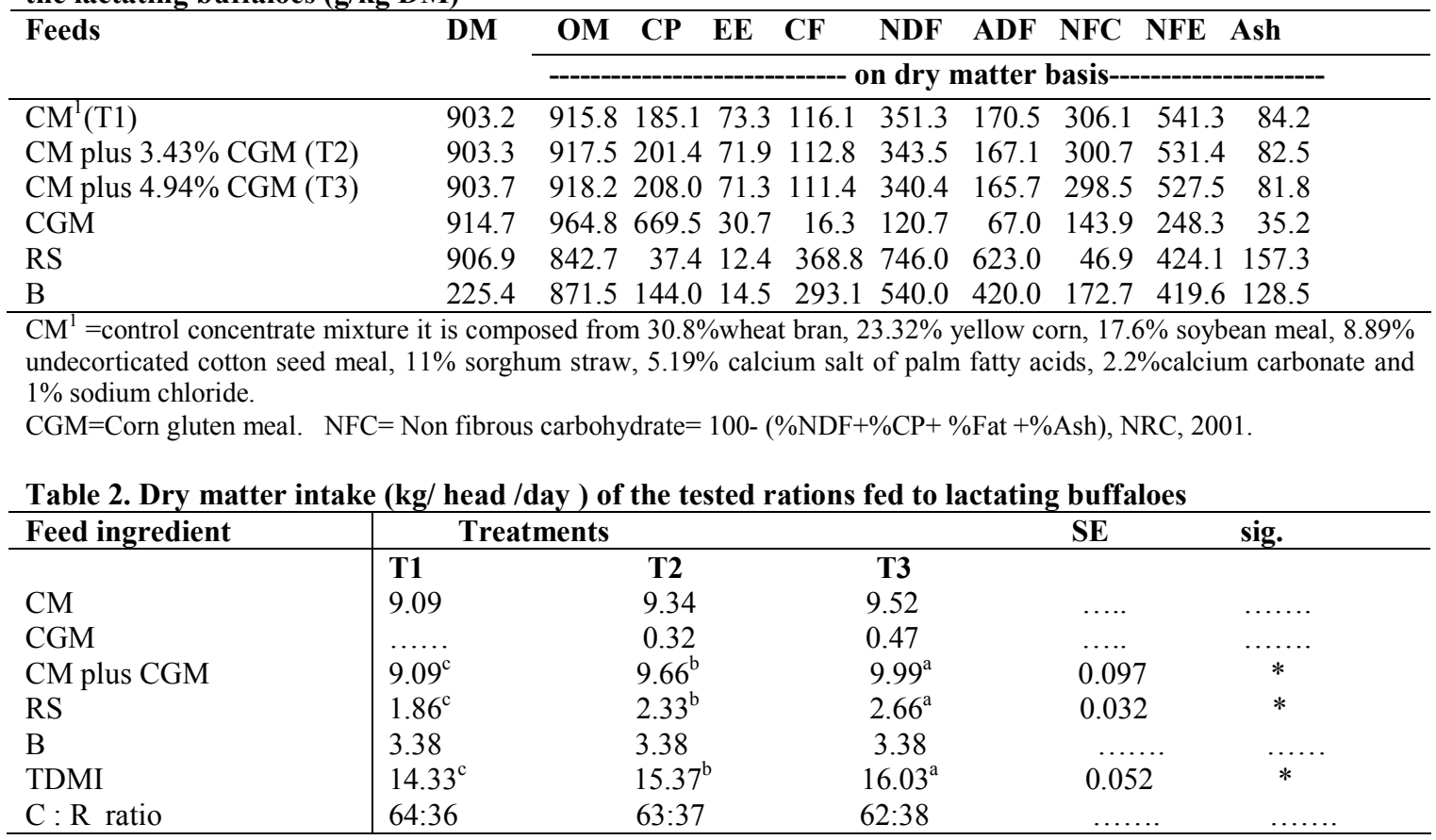

$\mathrm{T} 1=$ control treatment $\quad \mathrm{T} 2=\mathrm{T} 1+3.43 \% \mathrm{CGM} \quad \mathrm{T} 3=\mathrm{T} 1+4.94 \% \mathrm{CGM}$

$\mathrm{RS}=$ Rice straw $\mathrm{B}=$ Berseem $\quad \mathrm{TDMI}=$ Total dry matter intake

Sig. $=$ Significance $(\mathrm{P}<0.05)$ Means in the same raw with different super scripts are significantly $(\mathrm{P}<0.05)$ different

Table 3. calculated nutrients content (g/kg DM) of rations consumed by lactating buffaloes

\begin{tabular}{lccc}
\hline & \multicolumn{2}{c}{ Treatments } & T3 \\
Nutrient & T1 & T2 & 761.53 \\
DM & 743.81 & 755.01 & 897.19 \\
OM & 895.86 & 897.03 & 179.79 \\
CP & 156.31 & 173.73 & 48.36 \\
EE & 51.53 & 49.40 & 189.64 \\
CF & 190.65 & 189.25 & 443.35 \\
NDF & 447.04 & 443.10 & 292.31 \\
ADF & 288.08 & 289.74 & 225.69 \\
NFC & 240.99 & 230.81 & 479.41 \\
NFE & 497.38 & 484.65 & 102.81 \\
Ash & 104.14 & 102.97 & \\
\hline DM $=$ Dry matter, OM=Organic matter, CP=Crude protein & \\
EE=Ether extract, CF=Crude fiber, NDF=Neutral detergent & \\
Fiber ADF = Acid detergent fiber, NFC=Non fibrous carbohydrate & NFE=Nitrogen free extract
\end{tabular}

Increasing the level of CGM supplementation from 0 to 10 or $15 \%$ of the MP requirement increased significantly $(\mathrm{P}<0.05)$ TDMI by 7.26 and $11.86 \%$ when T2 and T3 were compared with T1. Even though the concentrate: roughage ratios were nearly similar (Table 2).

Digestibility and feeding value results are displayed in Table 4. The DM digestibility coefficients (DMD) were significantly $(\mathrm{P}<0.05)$ affected by the experimental treatments. Rations supplemented with CGM showed significantly $(\mathrm{P}<0.05)$ greater $\mathrm{DMD}$ values by 3.31 and $6.48 \%$ for $\mathrm{T} 2$ and $\mathrm{T} 3$ respectively than T1. Difference between $\mathrm{T} 2$ and $\mathrm{T} 3$ was significant $(\mathrm{P}<0.05)$. The results revealed also that organic matter digestibility (OMD) coefficient increased significantly $(\mathrm{P}<0.05)$ by $3.11 \%$ 
upon feeding T3 as compared with feeding T1. There was no significant difference between $\mathrm{T} 2$ and $\mathrm{T} 1$ or $\mathrm{T} 3$ in this respect. Crude protein digestibility (CPD) coefficient differed significantly $(\mathrm{P}<0.05)$ due to CGM supplementation (Table 4). The enhancement was calculated to be 5.33 and $7.48 \%$ for $\mathrm{T} 2$ and $\mathrm{T} 3$ respectively above $\mathrm{T} 1$. Also $\mathrm{T} 3$ was greater than $\mathrm{T} 2$ by $2.04 \%$ in CPD. The difference was significant $(\mathrm{P}<0.05)$.Digestibility coefficients of $\mathrm{EE}, \mathrm{CF}, \mathrm{ADF}$, NFC and NFE were not significantly different among treatments. However NDF digestibility (NDFD) was significantly $(\mathrm{P}<0.05)$ increased by 2.36 and $5.87 \%$ when $\mathrm{T} 2$ and $\mathrm{T} 3$ respectively compared with $\mathrm{T} 1$.The difference between T3 and T2 was significant $(\mathrm{P}<0.05)$. The value was $3.43 \%$ in favor $\mathrm{T} 3$ above $\mathrm{T} 2$ (Table 4).Total nutrients digestibility (TDN) values were $730.8,738.2$ and $743.1 \mathrm{~g} / \mathrm{kg} \mathrm{DM}$ for T1, T2 and T3 consecutively. No significant difference could be detected among treatments in this regard.

Table 4. Digestibility coefficient of feed nutrients and the feeding value of the tested rations

\begin{tabular}{lcccccc}
\hline \multirow{2}{*}{ Nutrients } & \multicolumn{3}{c}{ Treatments } & SE & Sig. \\
\cline { 2 - 5 } & T1 & T2 & T3 & & & \\
\hline DM & $681.8^{\mathrm{c}}$ & $704.4^{\mathrm{b}}$ & $726.0^{\mathrm{a}}$ & 5.12 & $*$ & \\
OM & $756.0^{\mathrm{b}}$ & $766.5^{\mathrm{ab}}$ & $779.5^{\mathrm{a}}$ & 3.57 & $*$ & \\
CP & $780.5^{\mathrm{c}}$ & $822.1^{\mathrm{b}}$ & $838.9^{\mathrm{a}}$ & 1.89 & $*$ \\
EE & 824.4 & 824.2 & 823.9 & 1.73 & $\mathrm{NS}$ \\
CF & 653.3 & 664.7 & 666.2 & 4.74 & $\mathrm{NS}$ \\
NDF & $550.0^{\mathrm{c}}$ & $563.0^{\mathrm{b}}$ & $582.3^{\mathrm{a}}$ & 3.86 & $*$ \\
ADF & 450.6 & 468.7 & 478.9 & 7.42 & $\mathrm{NS}$ \\
NFC & 709.8 & 697.9 & 688.0 & 8.28 & $\mathrm{NS}$ \\
NFE & 781.5 & 779.9 & 784.8 & 5.93 & $\mathrm{NS}$ \\
TDN & 730.3 & 738.2 & 743.1 & 7.13 & $\mathrm{NS}$ \\
\hline
\end{tabular}

$\mathrm{DM}=$ Dry matter, $\mathrm{OM}=$ Organic matter, $\mathrm{CP}=$ Crude protein, $\mathrm{EE}=$ Ether extract, $\mathrm{CF}=$ Crude fiber

$\mathrm{NDF}=$ Neutral detergent fiber, $\mathrm{ADF}=$ Acid detergent fiber, $\mathrm{NFC}=$ Non fibrous carbohydrate, $\mathrm{NFE}=$ Nitrogen free extract, Sig. $=$ Significance $(\mathrm{P}<0.05)$,

Means in the same raw with different super scripts are significantly $(\mathrm{P}<0.05)$ different

Data of milk yield and composition and efficiencies of feed nutrients utilization for milk constituent's synthesis are shown in Table 5. Supplementation of CGM to the lactating buffaloes rations significantly $(\mathrm{P}<0.05)$ increased actual milk produced. The values were $9.75,11.03$ and 11.10 $\mathrm{kg} /$ head/day. While, the yield of $7 \%$ fat corrected milk (7\%FCM) was $11.01, \quad 12.25$ and 12.09 $\mathrm{kg} /$ head/day when treatments $\mathrm{T} 1, \mathrm{~T} 2$ and $\mathrm{T} 3$ were fed respectively. The differences were significant $(\mathrm{P}<0.05)$. The increments in actual milk yield were 13.13 and $13.85 \%$ when $\mathrm{T} 2$ or $\mathrm{T} 3$ were fed instead of feeding $\mathrm{T} 1$. While, the increments in $7 \% \mathrm{FCM}$ were 11.26 and $9.81 \%$ when $\mathrm{T} 2$ and $\mathrm{T} 3$ were respectively fed instead of feeding $\mathrm{T} 1$. No significant difference was found between feeding $\mathrm{T} 2$ or $\mathrm{T} 3$ in this respect. On the same trend the protein and fat corrected milk yield was affected with CGM supplementation. The yields were 15.22, 16.93 and $16.83 \mathrm{~kg} / \mathrm{head} /$ day when $\mathrm{T} 1, \mathrm{~T} 2$ and $\mathrm{T} 3$ were fed respectively. The improvements attained were 11.24 and $10.58 \%$ for feeding T2 or T3 above feeding T1 the control ration. On the line the yields of energy corrected milk were $16.60,18.74$ and 18.63 $\mathrm{kg} /$ head/day. The increments were 12.89 and $12.23 \%$ when $\mathrm{T} 2$ or $\mathrm{T} 3$ were fed than feeding T1.No significant difference was found between treatments in $7 \% \mathrm{FCM} / \mathrm{TDMI}$. The efficiencies were $0.77,0.80$ and $0.75 \mathrm{~kg} 7 \% \mathrm{FCM} / \mathrm{kg}$ TDMI when $\mathrm{T} 1, \mathrm{~T} 2$ and $\mathrm{T} 3$ respectively were fed. The milk energy (Mega calorie $/ \mathrm{kg}$ ) were $1.16,1.14$ and 1.12 when the experimental treatments were in the order T1, T2 and T3 fed.
The milk constituent's concentrations and its yield are presented in Table 5. Significant difference $(\mathrm{P}<0.05)$ was found in protein content. The highest concentration was for feeding T3 $(44.7 \mathrm{~g} / \mathrm{kg})$, while the lowest concentration was $41.5 \mathrm{~g} / \mathrm{kg}$ when $\mathrm{T} 1$ was fed. Difference between T2 and T3 was not significant in this respect. The increments were 6.02 and $7.71 \%$ for $\mathrm{T} 2$ and $\mathrm{T} 3$ respectively above $\mathrm{T} 1 . \mathrm{Milk}$ fat concentrations were $82.2,80.5$ and78.5 $(\mathrm{g} / \mathrm{kg})$ whenT1, T2 and T3 were fed respectively. No significant difference was found between treatments. No significant difference was found between treatments in milk concentrations of lactose, total solids and solids not fat ( $\mathrm{g} / \mathrm{kg}$, Table 5).

Yields of milk constituents (fat, protein and lactose) were affected significantly $(\mathrm{P}<0.05)$ by CGM supplementation. The increase in fat yield was 11.25 and $8.75 \%$ for feeding $\mathrm{T} 2$ or $\mathrm{T} 3$ above $\mathrm{T} 1$. While, the increase in protein yield was 19.51 and $21.95 \%$ when T2 or T3 was fed respectively instead of T1. The yields of milk lactose were on the same trend. Feeding T2 or T3 increased lactose yield $(\mathrm{g} / \mathrm{kg})$ by 13.64 and $18.18 \%$ successively above feeding T1 (the control treatment). No significant difference was found between $\mathrm{T} 2$ and $\mathrm{T} 3$ in these regards.

The efficiency of utilizing feed protein for milk protein synthesis was $0.18,0.18$ and 0.17 (milk protein / feed protein), while the efficiency of utilizing MP intake for milk protein synthesis was 0.41, 0.42 and 0.40 (milk protein / MP intake - MP requirement for maintenance) when the tested treatments in the order T1, T2 and T3 were fed. 
Table 5. Milk yield and composition of buffaloes fed the tested rations

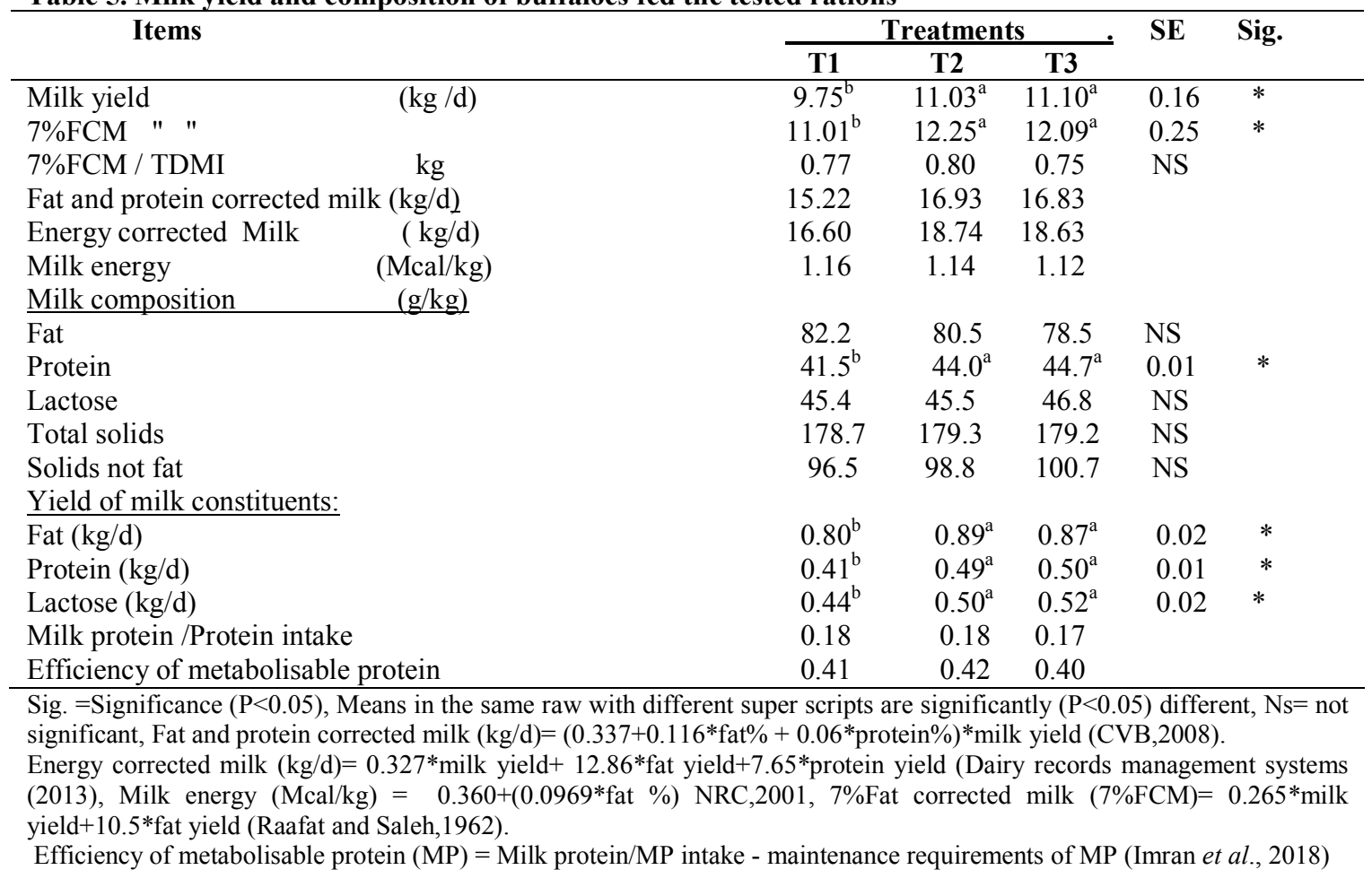

\section{DISCUSSION}

The control concentrate mixture(CM) used in this experiment contained 185.1g CP, 73.3 g EE and 51.9 $\mathrm{g}$ ca salt of palm fatty acids (CaPFA) $/ \mathrm{kg}$ DM that provide $111.37 \mathrm{~g}$ MP and $12.91 \mathrm{MJ} \mathrm{ME} / \mathrm{kg} \mathrm{DM}$. Considering the nutritional content of the whole ration consumed (CM,RS and Barseem) the calculated CP concentrations would be 156.31 , 173.73 and $179.79 \mathrm{~g} \mathrm{CP} / \mathrm{kg} \mathrm{DM}$ of the three experimental rations, which were in the recommended range for lactating cattle 163.7-172.5 g CP/kg DM (NRC., 2001 and Hugo et al., 2010). The calculated EE extract concentrations in the whole ration consumed were in the range of $48.36-51.53$ $\mathrm{g} / \mathrm{kg} \mathrm{DM}$ which is acceptable and advisable not to exceed $70 \mathrm{~g} / \mathrm{kg}$ (Macdonald et al., 2010,Kellems and Curch, 2010 and Nichols et al.,2018).Inclusion of the roughage and forage sources in the diet logically decreased the CP, EE and NFE concentrations, while increased the CF and cell wall constituents (NDF and ADF Tables 1 and 3) as they are mainly sources for cell wall and fibrous constituents.

In this experiment, NFC concentrations were in the range of 225.69 to $240.99 \mathrm{~g} / \mathrm{kg} \mathrm{DM}$ of the ration consumed, while the recommended figure according to NRC (2001) is in the range of $32.0-43.0 \%$ of the ration as a maximum level. This means that rations were somewhat low in NFC concentration than NRC (2001) recommended level. In other words the tested rations were greater in fibrous materials. It is obvious that fibrous materials are required to stimulate rumination, salivation and buffer the rumen $\mathrm{pH}$ keeping the ruminal fermentation environment more convenient and giving better chance for microbial fermentation in the rumen. Upon this condition and CGM supplementation the TDMI was significantly $(\mathrm{P}<0.05)$ increased, not only but also the intake of $\mathrm{RS}$, that is the greatest source of cell wall constituents (NDF and ADF) was significantly $(\mathrm{P}<0.05)$ increased (Table, 2$)$.

Broderick (2003) showed a linear increase in DMI from 21.2 to 22.1 and $22.6 \mathrm{~kg} / \mathrm{d}$ as $\mathrm{CP}$ was increased from 15.1 to 16.7 and $18.4 \%$ of the diet. It is in agreement with our results as in the present experiment the $\mathrm{CP}$ concentrations of the ration consumed were increased from 156.31 to 173.73 and $179.79 \mathrm{~g} / \mathrm{kg}$ DM. In addition, Flis and Wattiaux (2005) reported that DMI of cows on excess level of undegradable protein (RUP) was $2.1 \mathrm{~kg} / \mathrm{d}$ higher than the NRC, 2001 recommended level of RUP.

Moreover the Digestibility of DM, OM, CP and NDF were significantly $(\mathrm{P}<0.05)$ enhanced (Table, 4). This significant improvement in digestibility may explain the significant increase in TDMI as the undigested portion of the feed bulk became less giving room for greater intake that help animals to feel satiety(Forbes,2000). These improvements in digestibility and intake results due to CGM supplementation may be explained in the shadow of its characteristics. It is a rich source of CP (669.5 $\mathrm{g} / \mathrm{kg} \mathrm{DM}$ ) of low degradability (42-61\%, NRC, 2001, Bateman et al., 2005). Imran et al. (2018) reported that CGM has the highest value of rumen undegradable protein (RUP) because of its high concentration of prolamine and glutelins and higher methionine/lysine ratio. Vandeharr (2005) mentioned that it has greater content of methionine $1.17 \%$ than 
other plant protein sources (soybean and undecorticated cotton seed meal). It has $5.9 \mathrm{~g}$ sulfur, $119 \mathrm{mg}$ iron $6.1 \mathrm{gPalmitic}$ acid $11.4 \mathrm{~g}$ oleic acid, 26.8 $\mathrm{g}$ linoleic acid, $24 \mathrm{mg}$ vitamin E, 60mg niacin and 363 $\mathrm{mg}$ choline/kg as fed (Inra, 2007).

These increments in TDMI and Digestibility's due to CGM supplementation means greater feed nutrients were absorbed and being available to the mammary gland tissues for milk constituent's synthesis. It is true, as actual milk and 7\% FCM yield were significantly $(\mathrm{P}<0.05)$ greater in treatment $\mathrm{T} 2$ and T3 than the control treatment (T1, Table 5). It is interesting to find that milk protein concentrations were significantly $(\mathrm{P}<0.05)$ increased due to CGM supplementation and its level. This positive result could be explained as the dietary $\mathrm{CP}$ protein concentration, TDMI and digestibility of $\mathrm{CP}$ all were significantly $(\mathrm{P}<0.05)$ increased (Tables 1,2 and 4).

No significant effect was clear among treatments in efficiency of utilization of dietary nutrients for milk constituent's synthesis. This may be explained as CGM was mainly source of protein. This result is in agreement with Imran et al. (2018) study. They work on replacing soybean meal with CGM. They reported that increasing $\mathrm{CP}$ supply from 15.2 to $18.4 \%$ significantly increased milk protein and lactose yield but decreased milk $\mathrm{N}$ efficiency by $10.9 \%$

Nichols et al. (2018) stated that milk protein concentration and yield were increased in response to protein supplementation, while milk fat and lactose concentration were increased in response to fat supplementation and were not affected by protein supplementation. Dijkstra et al. (2013) concluded that if available protein in the rumen exceeds post absorptive requirements, excess $\mathrm{NH}_{3}$ is produced and excreted as urea. Energy is required to process and excrete the surplus of $\mathrm{N}$, which increases heat production and decreased retained energy and milk energy (Reed et al.,2017). This may explain the resulted decrease in milk energy occurred in our results when $\mathrm{T} 2$ and $\mathrm{T} 3$ were fed in comparison with feeding T1 (Table, 5).

However, it could not be ignored that the yield of milk protein, fat and lactose $(\mathrm{kg} / \mathrm{d})$ were significantly $(\mathrm{P}<0.05)$ enhanced. No significant difference was found between the two supplementation levels of CGM (10 or $15 \%$ ) of the AFRC, 1993 standards of MP requirements for dairy cattle despite milk protein concentration.

In this case it is concluded that Supplementation of CGM in amount that represent $10 \%$ above the AFRC,1993 recommendations for MP of dairy cattle positively improved intake, digestibility and milk production .The MP requirement for lactating buffalo should be studied more extensively and in view of milk pricing system and milk industrial technology.

\section{REFERENCES}

AOAC., 2006. Official Methods of Analysis (18 ed.) Association of Official Analytical Chemists, Arlington, USA.
Abd-El Hakeem, M.A.; S.T.M.Fahmy; A.K.I.AbdElmoty; M.T. Sallam and A.A. Abd-ElGhani, 2017. Milk production and it's composition of Holstein dairy cattle fed rations containing different levels of rumen degradable protein supplemented or unsupplemented with protected amino acids. Proceeding of the $3^{\text {rd }}$ international conference on "Sustainable development of livestock production system", Egypt, Alexandria, November $7-9,2017$

Abu Hussein , E.R.M.; E.A.Gihad: T.M. El-Bedawy and M.H. Abdel-Gawad, 2003. Effect of dietary oilseed supplement on nutrient utilization, milk yield and composition of lactating buffaloes. Egyptian J. Anim. Prod. Vol.40: 27-41

AFRC, 1993. Energy and protein requirement of ruminants, Agriculture and Feed Research Center, Technical committee on responses to nutrients. CAB international, Wallingford, Oxon, OX 108 DE, U.K.

Arriola Apelo, S.I.; A.L. Bell; K. Estes; J. Ropelewski; M.J. de Veth and M.D. Hanigan, 2014. Effects of reduced dietary protein and supplemental rumen-protected essential amino acids on the nitrogen efficiency of dairy cows. J. Dairy Sci. 97: 5688- 5699.

Bateman, H.G.; J.H. Clark and M.R. Murphy, 2005. Development of a system to predict feed protein flow to the small intestine of cattle. J. Dairy Sci.,88:282

Boerman, J.P.; S.B. Potts; M.J. Vandehaar and A.L. Lock, 2015. Effects of part replacing dietary starch with fiber and fat on milk production and energy partitioning. J. Dairy Sci.98: 7264-7276.

British Standards Institution, 1962. British standards methods for determination of milk fat, the Gerber method. Bull. Pp. 962.

Broderick, G.A., 2003. Effects of varying dietary protein and energy level on the production of lactating dairy cows. J. Dairy Sci., 80:294

CVB (Centraal Veevoeder Bureau, 2008.CVB Table Ruminants 2008, series nr.43.CYB, The Hague, the Netherlands

Dairy Records System, 2013. Dairy Records Management System DHI Glossary, Accessed, June, 17,2013.http:www.drms.Org./PDF materials

Dijkstra, J.; O. Oenema; J.W. van Groenigen; J.W. Spek; A.M.van Vuuren and A. Bannink, 2013. Diet effects on urine composition of cattle and $\mathrm{N}_{2} \mathrm{O}$ emissions.Animal 7:292-302

Fahmy, S.T.M.; A.K.Abd-Elmoty; E.B. Soliman; S.M.S. Mustafa and E.M. Ibrahim, 2019. Digestibility, milk yield and composition of lactating buffaloes fed rations supplemented with calcium salt of palm fatty acids. The first international conference for animal production. September 10 - 14, Sharm El-Shekh, Egypt,

Flis, S. A. and M.A.Wattiaux, 2005. Effects of parity and supply of rumen-degraded and undegraded protein on production and nitrogen balance in Holsteins 
Forbes, J. M., 2000. Physiological and metabolic aspects of feed intake control In :Farm Animal Metabolism and Nutrition, Pp. 319, Ed. D' Mello, J.P.F. CABI publishing.

Gill, J. L. and W. T. Magee, 1976. Balanced twoperiod changeover designs for several treatments. J. Anim. Sci., 42: 775.

Ibrahim, E. M., 2007. Some productive performance and physiological responses of dairy buffaloes as affected by fat and protein supplementation. Ph.D. Thesis, Fac. Agric., Minia University, Egypt.

Hugo I., F.A.P Santos, C. M. M. B., P.S. Correia and J.C. Martinez, 2010. Diet crude protein content and sources for lactating dairy cattle. Sci. Agari (Piracicaba, Barz.), vol. 67 no 1.

Imran, M.; M.Q. Shahid; T.N. Pasha and M.N. Haque 2018. Effect of replacing soybean meal with corn gluten meal on milk production and nitrogen efficiency in Holstein cows. S. Afr. J. Anim. Sci. Vol. 48: (No. 3),590-599.

INRA, 2007. Alimentation des bovins, ovins et caprins, INRA publications Paris

Kellems, R.O. and Curch, D.C., 2010. Livestock Feeds and Feeding, Prentice Hall, Pearson.

McDonald, P, Edwards, R A, Greenhalgh J F D, Morgan, C.A, Sinclair, L. A. and R.G. Wilkinson, 2010. Animal nutrition, $7^{\text {th }}$ Edition Prentice Hall, Pearson.

Nichols ; A. Bannink, S. Pacheco; H.J. Van Valeng; J. Dijkstra and H. van Laars, 2018. Feed and nitrogen efficiency are affected differently but milk lactose production is stimulated equally when isoenergetic protein and fat is supplemented in lactating dairy cow diets. J. Dairy Sci. 101: 7857-7870.

NRC, 2001. Nutrient requirements of dairy cattle. $6^{\text {th }}$ rev. Ed National Academy Press, Washington, DC.

Reed, K.F.; H.C. Bonfa; J. Dijkstra, D.P. Casper and E. Kebrcab, 2017. Estimating the energetic cost of feeding excess dietary nitrogen to dairy cows.J.Dairy Sci. 100: 7116-7126.

Raafat, N. A. and M. S. Saleh, 1962. Two formulas for conversion of cow's and buffalo's milk of different fat percentages into milk of standard fat percentage. Proceeding of the $1^{\text {st }}$ Anim. Prod. Conference: p. 203, at Minia University, Egypt.

SAS, 1990. SAS user's guide: Statistics, Version 5 Ed. SAS Institute, INC., Cary, NC., USA.

Tripathi, M.K., 2014. Effect of nutrition on production, composition, fatty acids and nutraceutical properties of milk. J. Adv. Dairy Res., 2:2http://dx.doi.org/ 10.417212329888 x. 1000115

Vandeharr, J.J.M., 2005. Dairy Cattle In: Basic Animal Nutrition and Feeding, 5th Ed. John Wiley and Son, Inc. USA.

Van Keulen, J. and B. A. Young, 1977. Evaluation of acid-insoluble ash as a natural marker in ruminant digestibility studies. J. Anim. Sci., 44: 282.

Van Soest, PJ, J.B. Robertson and B.A. Lewis 1991. Methods for dietary fiber, neutral detergent fiber and nonstarch polysaccharides in relation to animal nutrition. J. Dairy sci. 74, $3583-3597$.

Weiss, W. P. and D. J. Wyatt, 2004. Digestible energy values of diets with different fat supplements when fed to lactating dairy cows. J. Dairy Sci., 87: 1446.

\section{المادة الغذائية المأكولة،المهضوم ،محصول اللبن ومكوناته للجاموسات الحلابة المغذاة على علائق مدعمة

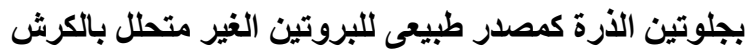 \\ سمير توفيق محمد فهمى، عبد المعطى خيرى، عصام بسيونى سليمان، سبد أحمد محمد، عماد الدين إبراهيم قسم الإنتاج الحيوانس والداجنى ، كلية الزراعة ، جامعة المنيا}

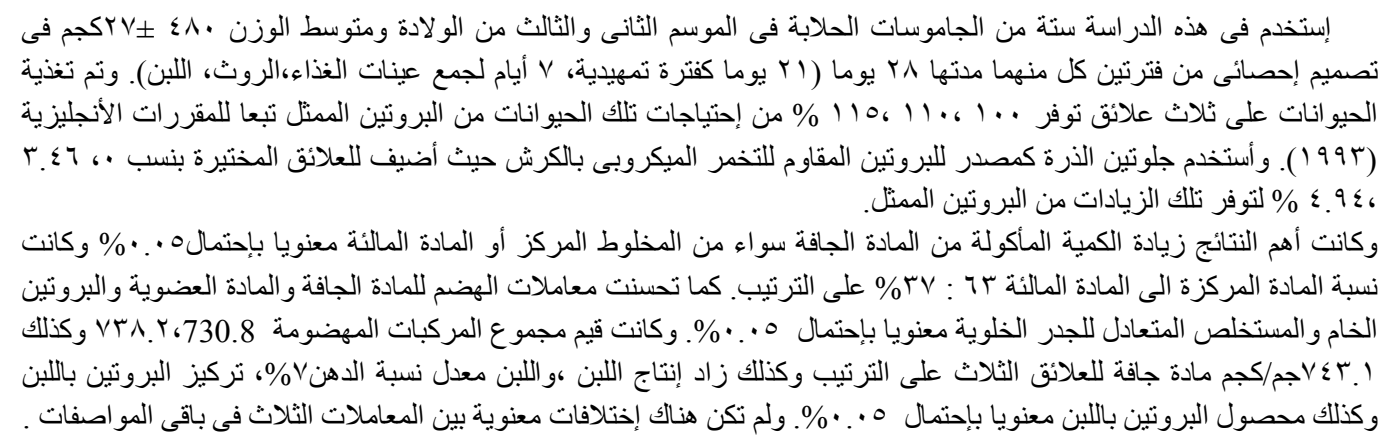

